\title{
Prevalence of Bacterial Vaginosis in Grenadian Women of Reproductive Age
}

\author{
K Brooks-Smith-Lowe, S Rodrigo
}

\begin{abstract}
Objectives: To determine the prevalence of bacterial vaginosis (BV) among Grenadian women of reproductive age using the routinely collected Pap smear data for the period January 2009 to December 2011.

Methods: A retrospective review of a cross-section of Pap smears was obtained for women between the ages of 15 and 49 years, using the national centralized data bank at the General Hospital in St George's, Grenada. Women aged younger or older than the sample group, as well as those who were reported as being menopausal or hysterectomized were excluded from the study. Demographic and laboratory data were collected and descriptive statistics reported.

Results: The prevalence of BV was 19.5\% for the three-year period among the 2677 females included in the analysis with the 20-29-year age group having the largest percentage of infection (43.6\%). An increase in the trend of prevalence between 2009 (16.1\%) and 2011 (21.4\%) was also observed. Candida vaginalis and Trichomonas vaginalis were present in $3.6 \%$ and $0.85 \%$, respectively. Additionally, atypical cells of unknown significance and cervical dysplasia were documented in 5.3\% and $1.8 \%$ of the smears, respectively.

Conclusion: Practicing physicians in Grenada need to consider increased screening for BV in women who may present with non-specific symptoms. Further research is necessary to determine the predisposing factors in Grenadian women and associations with the disease and to assist in the development of national education programmes to alter behavioural practices that could result in the acquisition and persistence of BV among women of reproductive age in Grenada.
\end{abstract}

Keywords: Bacterial vaginosis, Caribbean, Pap smear, vaginitis

\section{Prevalencia de la Vaginosis Bacteriana en Mujeres Granadinas en Edad Reproductiva}

K Brooks-Smith-Lowe, S Rodrigo

\begin{abstract}
RESUMEN
Objetivos: Determinar la prevalencia de vaginosis bacteriana (VB) entre mujeres granadinas de edad reproductiva utilizando datos de pruebas de Papanicolaou rutinariamente recolectados durante el período de enero de 2009 a diciembre de 2011.

Métodos: Se realizó una revisión retrospectiva de una muestra representativa de Papanicolau de mujeres entre las edades de 15 a 49 años, usando el Banco Nacional de Datos centralizados en el Hospital General de Saint George, Granada. Las mujeres de edad más jóvenes o mayores que el grupo de muestra, así como aquellas que se registraron como menopáusicas o histerectomizadas fueron excluidas del estudio. Datos demográficos y del laboratorio fueron recogidos, y se reportó la estadística descriptiva.

Resultados: La prevalencia de BV fue de 19,5\% para el periodo de tres años entre las 2677 hembras incluyeron en el análisis, presentando el grupo de edad de 20-29 años el mayor porcentaje de infección (43,6\%). También se observó un aumento en la tendencia de la prevalencia entre 2009 (16,1\%) y 2011 (21,4\%). Candida vaginalis y Trichomonas vaginalis estuvieron presentes en 3,6\% y 0,85\%, respec-
\end{abstract}

From: Department of Public Health and Preventive Medicine, St George's University, Grenada.
Correspondence: Dr K Brooks-Smith-Lowe, Department of Public Health and Preventive Medicine, St George's University, True Blue campus, St George's, Grenada, West Indies. E-mail: kecialowe@gmail.com 
tivamente. Además, se documentaron las células anormales de significación desconocida y displasia cervical en $5,3 \%$ y $1,8 \%$ de los frotis, respectivamente.

Conclusión: Los médicos en ejercicio en Granada necesitan considerar el aumento del tamizaje para la detección de BV en mujeres que puedan presentarse con síntomas no específicos. Se necesita continuar las investigaciones a fin de determinar los factores de predisposición en las mujeres Granadinas y las asociaciones con la enfermedad. Asimismo, es necesario ayudar al desarrollo de programas nacionales de educación encaminados a modificar aquellas conductas que podrían conducir a la adquisición y la persistencia de la BV entre las mujeres de edad reproductiva en Granada.

Palabras claves: Vaginosis bacteriana, Caribe, prueba de Papanicolaou, vaginitis

West Indian Med J 2013; 62 (7): 600

\section{INTRODUCTION}

Bacterial vaginosis (BV), a polymicrobial syndrome caused by an imbalance in the normal vaginal flora (1), occurs in 5 $50 \%$ of reproductive age women (2-4). Normal flora consists largely of hydrogen peroxide secreting Lactobacilli that maintain $\mathrm{pH}$ at 4.5 or less, and inhibit the proliferation of a host of bacteria associated with the development of BV (5). Bacterial vaginosis is an important public health issue since infected women may be at increased risk for HIV infection $(4,6)$, human papillomavirus (HPV) infection (7), cervical intraepithelial neoplasia (CIN) or dysplasia (8), pelvic inflammatory disease (9) and late miscarriage (10). Approximately $50 \%$ of women having BV are asymptomatic, however, many affected women may experience a grey homogenous or fishy malodorous vaginal discharge, abdominal pain, intermenstrual bleeding or prolonged menses (1, 4).

While the natural history and risk factors for $\mathrm{BV}$ are still unclear (3), there are many predisposing factors, the strongest being vaginal douching (1) which is believed to alter the vaginal microflora and possibly increase overgrowth of BV-associated bacteria. Holzman et al (11) noted that there were significant increases in the prevalence of $\mathrm{BV}$ in 18-40 year olds who used vaginal douches before 20 years of age and douched at least once or twice per month. In a United Kingdom study of women with and without BV, genital hygiene practice was strongly associated with the two-fold increase in the risk of the disease among black Caribbean women when compared with white women; the former group being three times more likely to use antiseptic solutions for douching (12).

Studies have shown that black women are at increased risk for BV $(1,12,13)$. One explanation may be that physiologically, black women have a higher vaginal $\mathrm{pH}$, predisposing them to BV (12). In addition to ethnicity, other risk factors include number of sexual partners, age, lower education levels, lower socio-economic status, smoking, and alcohol consumption. Oral contraceptive use has been found to be protective $(1,3,4)$.
Bacterial vaginosis is unique since it is more commonly found in women over 25 years of age, in contrast to most sexually transmitted infections (STIs) that are prevalent in persons under 25 years of age who tend to have more sexual partners and more frequent partner changes (1). While BV is associated with sexually activity, it is not considered a strictly sexually transmitted disease since it has also been observed in virgins (4). Bacterial vaginosis is also more prevalent among lesbians who usually report lower rates of STIs (6).

There are several methods for diagnosing BV, categorized into two main groups, clinical criteria and laboratorybased testing: namely Amsel's criteria, Nugent score and Pap smear $(4,14)$. Amsel's criteria is the most widely accepted clinical method to diagnose BV due to its utility for immediate diagnosis in an office setting; however, it may not be as accurate as Nugent's criteria (4). The Nugent score is considered the gold standard for BV diagnosis in the laboratory (15), whereas the Pap smear is a common cytological screening test for precancerous lesions, that can also be used to diagnose BV.

There have been several published studies reporting on the methods of diagnosing BV $(14,16,17)$. In a one-year prospective study of Turkish women, Tokyol et al (16) found that Pap smear had a sensitivity of $43.1 \%$ and a specificity of 93.6\% when compared with the Nugent method suggesting that routine Pap smears are not sensitive enough to be used as a screening test, but is specific enough to diagnose BV when it is positive. However, in another Turkish study, a comparison of the three methods for BV diagnosis concluded that the sensitivity and specificity of the Pap smear was 93\% and $94 \%$ (17). The authors stated that lower reported rates of sensitivity in Pap smears may be due to non-examination of the routinely collected smears by a cytopathologist.

There are very little data existing on the prevalence of $\mathrm{BV}$ in Caribbean women. In Grenada, BV is diagnosed from routine Pap smears, however, the prevalence has not been reported. Annually, 4000-4500 Pap smears are collected at the general hospital, government health centres and clinics, and private medical facilities including the Grenada Planned 
Parenthood Association; with all smears processed at the General Hospital laboratory. The results of the Pap smear are reported according to the Bethesda systems, where cells are classed as normal or abnormal. Abnormal cells are divided into atypical cells of unknown significance (ASCUS), and two classes of dysplasia (low-grade [LGSIL] and high-grade squamous intra-epithelial lesions [HGSIL]). The aim of this study was to examine Pap smear data and determine the prevalence of BV among Grenadian women of reproductive age.

\section{SUBJECTS AND METHODS}

This retrospective study included Grenadian women aged 15-49 years who had a Pap smear between January 2009 and December 2011, with a reported diagnosis of BV. Women reported as being menopausal or hysterectomized were excluded from the study. Approval for this study was obtained from the St George's Univeristy Institutional Review Board and the Ministry of Health, Grenada.

Data on BV-postive women were extracted from the Pap smear reports and patient records at the pathology laboratory of the General Hospital. Data collected included: age, occupation, parish of residence, parity, contraceptive method, presence of candida or trichomonas infections, ASCUS, and the presence of dysplasia (LGSIL and HGSIL). Data were analysed using PASW Statistics 18 (SPSS, Inc, 2009, Chicago, IL). Ordinal logistic regression was used to determine the relationship between the predictors (age [15$19,20-29,30-39,40-49$ years $]$ and parity $[0,1, \geq 2]$ groups), and cervical pathology (normal, ASCUS and dysplasia).

\section{RESULTS}

Over the three-year period, 3069 women were diagnosed with BV, however, 392 women were excluded due to age and menopausal status. Eligible women (2677) had a mean $( \pm \mathrm{SD})$ age of $32.1( \pm 8.8)$ years, were between 20 and 29 years (43.6\%), employed (76\%), resided in St George's $(43.9 \%)$, had at least one child $(77.8 \%)$ and used some form of birth control [70.2\%] (Table 1).

The three-year prevalence of BV was $19.5 \%$ (95\% CI: $18.9 \%, 20.2 \%$ ) with an increase in the prevalence from 2009 to 2011 (Table 2). The diagnosis of ASCUS was noted for $5.3 \%$ of the Pap smears, and dysplasia detected in $54(2.02 \%)$ of the smears. In addition to $\mathrm{BV}$, other vaginal infections were detected on the Pap smears (Table 2), the most common co-infection being candida $(3.6 \%, 95 \%$ CI: $2.9,4.3)$.

There was a significant difference in pathology when nulliparous women were compared with those having parity of two or more (OR $=0.51,95 \% \mathrm{CI}: 0.31,0.83, p=0.007)$. No statistically significant difference was noted in the analysis with age group.
Table 1: Characteristics of Grenadian women 15-49 years diagnosed with bacterial vaginosis

\begin{tabular}{|c|c|c|}
\hline Characteristics & $\mathbf{n}$ & $\%$ \\
\hline \multicolumn{3}{|l|}{ Age categories (years) } \\
\hline $15-19$ & 135 & 5.0 \\
\hline $20-29$ & 1166 & 43.6 \\
\hline $30-39$ & 766 & 28.6 \\
\hline $40-49$ & 610 & 22.8 \\
\hline \multicolumn{3}{|l|}{ Parity } \\
\hline Nulliparous & 568 & 22.2 \\
\hline Parous & 1988 & 77.8 \\
\hline \multicolumn{3}{|l|}{ Contraceptive use } \\
\hline Yes & 543 & 70.2 \\
\hline No & 270 & 29.8 \\
\hline \multicolumn{3}{|l|}{ Current contraceptive use } \\
\hline Hormonal & 286 & 37.0 \\
\hline Male condom & 139 & 18.0 \\
\hline Intrauterine device & 41 & 5.3 \\
\hline Tubal sterilization & 26 & 1.0 \\
\hline Other & 51 & 6.6 \\
\hline No contraceptive & 270 & 29.8 \\
\hline \multicolumn{3}{|l|}{ Employment status } \\
\hline Employed & 1772 & 76.0 \\
\hline Unemployed & 599 & 24.0 \\
\hline \multicolumn{3}{|l|}{ Occupation } \\
\hline Administrative/Finance & 340 & 14.5 \\
\hline Agriculture & 46 & 2.0 \\
\hline Education & 214 & 9.2 \\
\hline Health/Allied care & 288 & 12.3 \\
\hline Hospitality & 259 & 11.1 \\
\hline Sales/Customer service & 274 & 11.7 \\
\hline Self-employed & 182 & 7.9 \\
\hline Other & 94 & 4.0 \\
\hline Unemployed & 575 & 24.6 \\
\hline \multicolumn{3}{|l|}{ Parish of residence } \\
\hline St Andrew & 633 & 23.7 \\
\hline St David & 291 & 10.9 \\
\hline St George & 1172 & 43.9 \\
\hline St John & 165 & 6.2 \\
\hline St Mark & 82 & 3.1 \\
\hline St Patrick & 241 & 9.0 \\
\hline Carriacou/Petit Martinique & 84 & 3.1 \\
\hline
\end{tabular}

Table 2: Prevalence of bacterial vaginosis (BV) by year and cervical pathology in $\mathrm{BV}+$ women

\begin{tabular}{lcc}
\hline Pathology & Prevalence (\%) & $\mathbf{9 5 \%}$ CI \\
\hline BV by year & & \\
2009 & 16.1 & $15.0,17.2$ \\
2010 & 21.0 & $19.8,22.2$ \\
2011 & 21.4 & $20.3,22.6$ \\
Dysplasia (CIN) & 2.02 & $1.53,2.60$ \\
LGSIL (mild) & $79.6^{\mathrm{a}}$ & \\
HGSIL & $20.4^{\mathrm{a}}$ & \\
$\quad$ Moderate & $54.5^{\mathrm{b}}$ & \\
Severe & $45.5^{\mathrm{b}}$ & \\
Candida & 3.60 & $2.90,4.30$ \\
Trichomonas & 0.85 & $0.55,1.26$ \\
\hline
\end{tabular}

aPer cent of those diagnosed with dysplasia; ber cent of those diagnosed with HGSIL

$\mathrm{CIN}=$ cervical intraepithelial neoplasia, $\mathrm{LGSIL}=$ low grade squamous intraepithelial lesions, HGSIL = high grade squamous intra-epithelial lesions 


\section{DISCUSSION}

There has been no previously published study investigating the prevalance of $\mathrm{BV}$ in Grenada. The prevalence rate is considerably lower than that found in two previous studies conducted among pregnant women in Jamaica [44.1\%] (18) and sexually active women (33\%) in Barbados (19). The prevalance rate in this study is more comparable with that found in India, where rates ranged from $25.4 \%$ to $38.6 \%$ (20). In the current study, the prevalence $(\sim 20 \%)$ may not be a true representation since $50 \%$ of all BV-infected women are asymptomatic and may never seek medical attention (1). In addition, while symptomatic women may visit their healthcare providers, be treated empirically for a vaginal infection, a Pap smear may not be taken. Many Grenadian women of reproductive age have never had a Pap smear for several reasons, including ignorance of the importance of the procedure and fear of the unknown. Consequently, there would be an underestimate of the prevalence in this study.

The findings of this study are of public health importance given that this infection can cause morbidity including pain, intermenstrual bleeding and prolonged menses (1), with the potential for symptoms to become chronic and lead to infirmity (5). The increased risk of HIV and HPV infections, the increased incidence of carcinoma in situ and late miscarriage in these women is also cause for concern. There is a need to examine these possible sequelae in Grenada as this study has shown that one in five women suffers from BV.

The prevalence of Candida in this study was higher than that of Trichomonas, in contrast to Watcharotone et al (21) who suggested that BV-produced amines inhibit fungal multiplication. Generally $15-20 \%$ of women are colonized with yeast, many being asymptomatic (22), and persons with diabetes mellitus are at increased risk of vulvovaginal candidiasis (23). Diabetes is highly prevalent in the Caribbean hence this may explain the findings in this study (24).

This study found a statistically significant association between parity and cervial pathology. Nulliparous women had a lower odds of being in the dysplasia group when compared with women having parity of two or more. The fact that multiparous women were found to have a greater odds of having a smear indicating dysplasia is consistent with several studies which have found parity to be associated with dysplasia (CIN) and cancer $(25,26)$.

There are several limitations to this study since secondary data were used, one of which is incomplete data reporting. In addition, no data were collected on practices such as douching, number of sexual partners nor length of sexual relationship, limiting the investigation of links between behavioural and sexual factors with BV infection. Another limitation arises from the term 'contraceptive use' which is generally misinterpreted in Grenada to mean oral birth control tablets specifically, and not to just any method of birth control. Consequently, there were instances where no data were collected or inaccurately reported, even though condoms or other non-pill forms of contraception may be used. Of note, the form includes an 'other' category, and while 51 women $(6.6 \%)$ used other forms of birth con-trol, there was no specification as to the nature of 'other'. Education regarding birth control, and the various contraceptives used is therefore important during routine Pap smear testing to ensure accurate surveillance data collection.

Despite these limitations, this is the first study investigating the prevalence of $\mathrm{BV}$ in Grenada. One major strength of this study is that all the Pap smears are processed at the same site. In addition, only two cytotechnicians diagnose all pathological findings, evaluating and re-evaluating the slides before confirming diagnoses, therefore decreasing inter-observer variability.

This study highlights the need for a higher index of suspicion regarding BV in women who may present with some of the non-specific symptoms and for further investigation of this polymicrobial, sexually-associated infection. Since BV is linked to douching, further research is necessary to determine if this practice is true in the Grenadian community or if there are practices that are more prevalent. Addressing this infection could serve to decrease morbidity, the risk of acquiring HIV and HPV infections, and the development of cervical cancer in Grenadian women. Further research can affect change in behavioural practices that impact on the acquisition and persistence of BV among women of reproductive age in Grenada.

\section{ACKNOWLEDGEMENTS}

Special thanks to Mrs Veronica Mapp-Alexander who facilitated access to the original data at the pathology laboratory. Gratitude is also extended to Mrs Esther Marryshow, Misses Malaika and Sharifa Brooks-SmithLowe who gave their invaluable assistance during data collection and compilation.

\section{REFERENCES}

1. Morris M, Nicoll A, Simms I, Wilson J, Catchpole M. Bacterial vaginosis: a public health review. BJOG 2001; 108: 439-50. Epub 2001 May 23.

2. Fethers KA, Fairley CK, Hocking JS, Gurrin LC, Bradshaw CS. Sexual risk factors and bacterial vaginosis: a systematic review and metaanalysis. Clin Infect Dis. 2008; 47: 1426-35. Epub 2008 Oct 25.

3. Jones FR, Miller G, Gadea N, Meza R, Leon S, Perez J et al. Prevalence of bacterial vaginosis among young women in low-income populations of coastal Peru. Int J STD AIDS 2007; 18: 188-92. Epub 2007 Mar 17.

4. Money D. The laboratory diagnosis of bacterial vaginosis. Can J Infect Dis Med Microbiol 2005; 16: 77-9. Epub 2007 Dec 27.

5. Hay P. Recurrent bacterial vaginosis. Curr Opin Infect Dis 2009; 22: 82-6. Epub 2009 June 18.

6. Morris MC, Rogers PA, Kinghorn GR. Is bacterial vaginosis a sexually transmitted infection? Sex Transm Infect 2001; 77: 63-8. Epub 2001 Feb 7.

7. King CC, Jamieson DJ, Wiener J, Cu-Uvin S, Klein RS, Rompalo AM et al. Bacterial vaginosis and the natural history of human papillomavirus. Infect Dis Obstet Gynecol 2011; 2011: 1-8.

8. Nam KH, Kim YT, Kim SR, Kim SW, Kim JW, Lee MK et al. Association between bacterial vaginosis and cervical intraepithelial neoplasia. J Gynecol Oncol 2009; 20: 39. 
9. Ness RB, Kip KE, Hillier SL, Soper DE, Stamm CA, Sweet RL et al. A cluster analysis of bacterial vaginosis-associated microflora and pelvic inflammatory disease. Am J Epidemiol 2005; 162: 585-90. Epub 2005 Aug 12.

10. Llahi-Camp JM, Rai R, Ison C, Regan L, Taylor-Robinson D. Association of bacterial vaginosis with a history of second trimester miscarriage. Hum Reprod 1996; 11: 1575-8. Epub 1996 Jul 01.

11. Holzman C, Leventhal JM, Qiu H, Jones NM, Wang J. Factors linked to bacterial vaginosis in nonpregnant women. Am J Public Health 2001; 91: 1664-70. Epub 2001 Sep 28.

12. Rajamanoharan S, Low N, Jones SB, Pozniak AL. Bacterial vaginosis, ethnicity, and the use of genital cleaning agents: a case control study. Sex Transm Dis 1999; 26: 404-9. Epub 1999 Aug 8.

13. Goldenberg RL, Klebanoff MA, Nugent R, Krohn MA, Hillier S, Andrews WW. Bacterial colonization of the vagina during pregnancy in four ethnic groups. Vaginal Infections and Prematurity Study Group. Am J Obstet Gynecol 1996; 174: 1618-21. Epub 1996 May 1.

14. Mohanty S, Sood S, Kapil A, Mittal S. Interobserver variation in the interpretation of Nugent scoring method for diagnosis of bacterial vaginosis. Indian J Med Res 2010; 131: 88-91. Epub 2010 Feb 20.

15. Sha BE, Chen HY, Wang QJ, Zariffard MR, Cohen MH, Spear GT. Utility of Amsel criteria, Nugent score, and quantitative PCR for Gardnerella vaginalis, Mycoplasma hominis, and Lactobacillus spp. for diagnosis of bacterial vaginosis in human immunodeficiency virusinfected women. J Clin Microbiol 2005; 43: 4607-12. Epub 2005 Sept 8.

16. Tokyol C, Aktepe OC, Cevrioglu AS, Altindis M, Dilek FH. Bacterial vaginosis: comparison of Pap smear and microbiological test results. Mod Pathol 2004; 17: 857-60. Epub 2004 Apr 10.

17. Vardar E, Maral I, Inal M, Ozguder O, Tasli F, Postaci H. Comparison of Gram stain and Pap smear procedures in the diagnosis of bacterial vaginosis. Infect Dis Obstet Gynecol 2002; 10: 203-7. Epub 2003 Mar 22.

18. Kamara P, Hylton-Kong T, Brathwaite A, Del Rosario GR, Kristensen $\mathrm{S}$, Patrick $\mathrm{N}$ et al. Vaginal infections in pregnant women in Jamaica: prevalence and risk factors. Int J STD AIDS 2000; 11: 516-20. Epub 2000 Sep 16.

19. Levett PN, Taruvinga M, Maheswaran K, Rotchell Y. Genital tract infections in sexually active women in Barbados. West Indian Med J 1995; 44: 128-9. Epub 1995 Dec 1.

20. Bhalla P, Chawla R, Garg S, Singh MM, Raina U, Bhalla R et al. Prevalence of bacterial vaginosis among women in Delhi, India. Indian J Med Res 2007; 125: 167-72. Epub 2007 Apr 14.

21. Watcharotone W, Sirimai K, Kiriwat O, Nukoolkarn P, Watcharaprapapong O, Pibulmanee $\mathrm{S}$ et al. Prevalence of bacterial vaginosis in Thai women attending the family planning clinic, Siriraj Hospital. J Med Assoc Thai 2004; 87: 1419-24. Epub 2005 Apr 13.

22. Nyirjesy P. Chronic vulvovaginal candidiasis. Am Fam Physician 2001; 63: 697-702. Epub 2001 Mar 10

23. Goswami D, Goswami R, Banerjee U, Dadhwal V, Miglani S, Lattif AA et al. Pattern of Candida species isolated from patients with diabetes mellitus and vulvovaginal candidiasis and their response to single dose oral fluconazole therapy. J Infect 2006; 52: 111-7.

24. Hennis A, Wu S-Y, Nemesure B, Li X, Leske MC, Group fTBES. Diabetes in a Caribbean population: epidemiological profile and implications. Int J Epidemiol 2002; 31: 234-9.

25. Misra JS, Srivastava S, Singh U, Srivastava AN. Risk-factors and strategies for control of carcinoma cervix in India: hospital based cytological screening experience of 35 years. Indian J Cancer 2009; 46: 155-9. Epub 2009 Apr 7.

26. Sun XG, Ma SQ, Zhang JX, Wu M. Predictors and clinical significance of the positive cone margin in cervical intraepithelial neoplasia III patients. Chin Med J (Engl) 2009; 122: 367-72. Epub 2009 Mar 24. 